\title{
Evaluation of Kenaf Yarn Properties as Affected by Different Linear Densities for Woven Fabric Laminated Composite Production
}

(Kajian ke atas Sifat Benang Kenaf Kesan daripada Perbezaan Ketumpatan Linear untuk Penghasilan Fabrik Tenunan Komposit Berlaminasi)

\author{
Aisyah Humaira AliaS*, PARIDAH MD. TAHIR, Khalina ABDAn, MoHd SAPUAN SAlit, \\ MD. SAIDIN WAHAB \& MOHD PAHMI SAIMAN
}

\begin{abstract}
Currently, there is a growing interest of using woven material in composite production for many applications such as structural applications, non-structural applications, household utilities, parts for automobile, aerospace components, flooring and ballistic laminate composites. The structure and properties of the woven fabric is very important as it dictate the woven composite properties. The properties of yarn like linear density, twist factor and strength can influence most of the woven fabric properties. Strength of woven fabric is one of the most important properties which make it superior in final composite applications. In this study, the effects of linear density i.e. 500, 1000, 1500 and 2000 tex on physical and mechanical properties of kenaf yarn were evaluated. The assessment on twist type, twist angle, yarn diameter, yarn structure, fibre density, moisture content, water absorption and mechanical properties were carried out on kenaf yarns. The yarn mechanical properties were tested on the tensile strength, Young's Modulus and elongation. It was found that, different linear density of yarn exhibited different behavior of yarn properties. Higher linear density yarn produced wider yarn diameter compared to lower linear density yarn, resulting to higher fibre and moisture content yarn. Yarn tensile strength has increased by 46\% when linear density was changed from 500 to 2000 tex due to higher amount of individual fibres. However, for Young's Modulus, the values reduced as the yarn linear density increased due to several factors including number of fibres and moisture content of yarn.
\end{abstract}

Keywords: Linear density; moisture content; twist angle; yarn

\section{ABSTRAK}

Pada masa ini, terdapat minat yang semakin meningkat bagi penggunaan bahan tenun dalam pengeluaran komposit untuk banyak aplikasi seperti aplikasi struktur, aplikasi bukan struktur, utiliti isi rumah, bahagian untuk kereta, komponen aeroangkasa, lantai dan komposit laminat balistik. Struktur dan sifat kain tenunan itu sangat penting kerana ia menentukan sifat komposit tenunan. Ciri-ciri benang seperti ketumpatan linear, faktor pintalan dan kekuatan boleh mempengaruhi kebanyakan sifat kain tenunan. Kekuatan kain tenunan adalah salah satu ciri yang paling penting yang menjadikannya unggul dalam aplikasi komposit akhir. Dalam kajian ini, kesan ketumpatan linear iaitu 500, 1000, 1500 dan 2000 tex dinilai terhadap sifat fizikal dan mekanikal benang kenaf. Penilaian daripada segi jenis pintalan, sudut pintalan, diameter benang, struktur benang, ketumpatan serat, kandungan lembapan, penyerapan air dan sifat mekanikal telah dijalankan pada benang kenaf. Ciri-ciri mekanikal benang telah diuji pada kekuatan tegangan, modulus Young dan pemanjangan. Kajian mendapati ketumpatan linear yang berbeza menghasilkan sifat benang yang berbeza. Benang dengan ketumpatan linear yang lebih tinggi menghasilkan diameter benang yang lebih luas berbanding benang berketumpatan linear yang lebih rendah menghasilkan benang dengan kandungan serat dan lembapan yang lebih tinggi. Kekuatan tegangan benang meningkat sebanyak 46\% apabila ketumpatan linear diubah daripada 500 hingga 2000 tex disebabkan oleh jumlah gentian individu yang lebih tinggi. Walau bagaimanapun, nilainya berkurangan bagi modulus Young kerana ketumpatan linear benang meningkat disebabkan oleh beberapa faktor termasuk bilangan serat dan kandungan lembapan benang.

Kata kunci: Benang; kandungan lembapan; ketumpatan linear; sudut pintalan

\section{INTRODUCTION}

Composite materials with natural fibres as a reinforcement agent have become interestingly used in many applications because of renewability and bio-degradability criteria of natural fibres, where synthetic composite cannot offer. One of the potential natural fibres that was used in composite materials is kenaf bast fibre, originate from the outer layer of kenaf stem. Kenaf fibre have good prospective as reinforcement agent for natural fibre composite because it has long fibre with good mechanical properties and high strength that can be converted to a high-performance composite. Table 1 shows the comparison of mechanical properties of kenaf fibre with another natural fibres that commonly used in composite industry. 
TABLE 1. Mechanical properties of different plant fibers

\begin{tabular}{lcccc}
\hline Fiber & $\begin{array}{c}\text { Density } \\
\left(\mathrm{g} / \mathrm{cm}^{2}\right)\end{array}$ & $\begin{array}{c}\text { Young's } \\
\text { modulus }(\mathrm{GPa})\end{array}$ & $\begin{array}{c}\text { Tensile strength } \\
(\mathrm{MPa})\end{array}$ & Elongation (\%) \\
\hline Bamboo & $0.6-1.1$ & $11-17$ & $140-230$ & - \\
Cotton & $1.5-1.6$ & $5.5-12.6$ & $287-597$ & $7-8$ \\
Flax & 1.54 & $27-85$ & $345-2000$ & $1-4$ \\
Hemp & 1.47 & $17-70$ & $368-800$ & 1.6 \\
Jute & 1.44 & $10-30$ & $393-773$ & $1.5-1.8$ \\
Kenaf & 1.2 & $14-53$ & $240-930$ & 1.6 \\
Ramie & $1.5-1.56$ & $27-128$ & $400-1000$ & $1-4$ \\
\hline
\end{tabular}

Sources: Bodros \& Baley 2008; Duval et al. 2011; Faruk et al. 2012; Ochi 2008; Oksman et al. 2003; Satyanarayana et al. 2009; Summerscales et al. 2010

Currently, there is a growing interest of using woven material in composite production for many applications such as structural applications (Baghaei et al. 2015; Jawaid et al. 2011; Khan et al. 2016), non-structural applications (Alavudeen et al. 2015; Pothan et al. 2003), household utilities (Abdellaoui et al. 2015; Sapuan et al. 2006; Sapuan \& Maleque 2005), parts for automobile and aerospace components (Le Duigou et al. 2011; Song et al. 2012), flooring (Dalbehera \& Acharya 2015), ballistic laminate composites applications (Azrin Hani et al. 2011; Yahaya et al. 2015) and bio-medical applications (Me et al. 2012). This type of composite is commonly known as textile composite or woven composite that made up from technical textile rather than conventional textile. The use of weaving technique that produce fabrics (also known as mats or performs), has received lots of attention because they provide superior mechanical properties. Moreover, woven composite also has ability to produce near net shape performs, high flexibility and stability.

Kenaf bast fibre can be processed into different ways such as long single fibre, fibre bundle, short fibre, oriented fibre and in a yarn form. In the woven fabric composite production, yarn is used because it offers flexible design as yarn can be weaved into specific structures to produce desirable properties for example higher mechanical properties and good permeability. The quality of yarn is important as it dominates later properties of woven fabric (or perform) and the final composite performance. Like any natural fibre composite, the strength and the stiffness of woven composite are dependent upon the properties of yarn. For instance, a fine yarn made of small tex number will result in an elastic and pliable fabric that has low drape ability. On the other hand, a coarse yarn with large tex number will produce a stiff fabric that has high drape. There is effect of fibre type, yarn quality and fabric attributes on woven fabric performance.

According to Goutianos et al. (2006), woven composites for high-end engineering applications can be develop from natural fibres by play around with the woven fabric quality. Types of yarn and yarn arrangement in the woven fabric would affect the physical and mechanical properties of the woven composites. In the production of woven composite, there are several aspects to be consider including yarn types, woven fabric properties, manufacturing technique and matrix types as well. It is important to study yarn structure essentially yarn types, linear density, sizes, mechanical properties and twist effect as they determine the structure of woven fabric. Many researchers have reported results incorporating yarn properties into composite properties (Chattopadhyay 2008; Gabrijelcic et al. 2008; Hani et al. 2013; Junior et al. 2004; Liu \& Hughes 2008; Saiman et al. 2014). It has been concluded that several yarn factors affect the woven fabric characteristics for composite application and it is important to pay particular attention in the selection of appropriate yarn types. However, there are less reported works on the effect of different linear densities on kenaf yarn properties for woven composite manufacture. Hence, the objectives of the current study were to evaluate the effects of linear density i.e. 500, 1000, 1500 and 2000 tex on physical and mechanical properties of kenaf yarn. Besides, scanning electron microscopy (SEM) analysis of the yarn structure was carried out.

\section{MATERIALS}

Kenaf yarn is the main material used. In this study, bobbins of continuous kenaf yarn were obtained from Juteko Co. Ltd., Bangladesh. There are four different yarn linear densities used namely: 500, 1000, 1500 and 2000 tex and evaluated for morphological, physical and mechanical properties.

\section{METHODS}

Hitachi 3400 scanning electron microscope (SEM) was used to measure the yarn structure and diameter. By means of a 20X microscope and randomly picked 150 readings, the yarn diameter was measured and recorded. The average of twist angle of yarn was also determined by taking the average of 10 measurements at different locations along the yarn axis.

The yarn linear density was calculated from the dry weights of kenaf yarn in accordance to ASTM D1907. The weight of these yarn samples were measured in a climate room $\left(65 \pm 5 \%\right.$ of $\mathrm{RH}$ at temperature of $\left.20 \pm 1^{\circ} \mathrm{C}\right)$ using a weighing balance. About ten yarn specimens with $1 \mathrm{~m}$ of yarn length were measured, using (1). 


$$
\text { Linear density }(\text { Tex })=\frac{W \times K}{l}
$$

where $\mathrm{W}$ is average weight of yarn $(\mathrm{g})$; $\mathrm{K}$ is constant value $(1000 \mathrm{~m} / \mathrm{g})$ for tex; and $l$ is length of the yarn $(\mathrm{m})$.

Fibre density was determined using (2) according to the ASTM D1895 standard. The mass of container (Mc) and mass of yarn in a container (My) was recorded and divided with the known volume of the container $(\mathrm{Vc})$.

$$
\text { Density, } \rho\left(\mathrm{g} / \mathrm{cm}_{3}\right)=\frac{M y-M c}{V c}
$$

The moisture content of yarn was determined after oven dried at $105^{\circ} \mathrm{C}$ for $24 \mathrm{~h}$ using the following equation:

$$
\text { Moisture content }(\%)=\frac{M_{1}-M_{2}}{M_{1}} \times 100
$$

where $M_{1}$ is the initial mass of yarn; and $M_{2}$ is mass of yarn after oven dried.

The number of yarn twist was determined using SDL Atlas Electric Twist Tester according to ASTM D1422 standard. Mechanical properties of yarn were measured by using a Testometric Universal Testing Machine (UTM) with a crosshead speed of $5 \mathrm{~mm} / \mathrm{min}$ and $10 \mathrm{kN}$ of applied load with gauge length of $3 \mathrm{~mm}$. Standard conditions in the testing room were $20 \pm 1^{\circ} \mathrm{C}$ and $65 \pm 5 \%$ of $\mathrm{RH}$. The reading of tensile strength, Young's Modulus and elongation were recorded. Minimum 20 tests for single yarn strength of each linear density count were tested according to ASTM D2256-02 standards.

The data was statistically analyzed using Statistical Analysis System (SAS) software. An analysis of Variance (ANOVA) was used to examine the effects of different yarn linear densities. Means that differ more than this value were considered as significantly different with each other and were ranked as a, b, c, d. Means followed by the letters are not significantly different with each other at $p \leq 0.05$.

\section{RESULTS AND DISCUSSION}

The effect of different yarn linear densities on the yarn physical, morphological and mechanical properties were determined.

\section{TWIST ANGLE, TWIST NUMBER AND MORPHOLOGICAL PROPERTIES}

The image in Figure 1 shows that the yarn structure consists of individual and bundle of fibres that are twisted together through spinning process. From the figure, all yarns are right twist or Z-twist, as opposed to S-twist due to most of the spinning equipment are designed for righthanded workers. The direction of a yarn's twist affects fabric properties and appearance (Mollanoori et al. 2012). Fabric with S-twist yarn will be more lustrous and softer than fabric from Z-twist yarn due to the orientation of the surface fibre in relation to yarn axis and the freedom of movement at the yarn intersections which is important in apparel industry. In this study, it was found that all yarns have same twist direction.

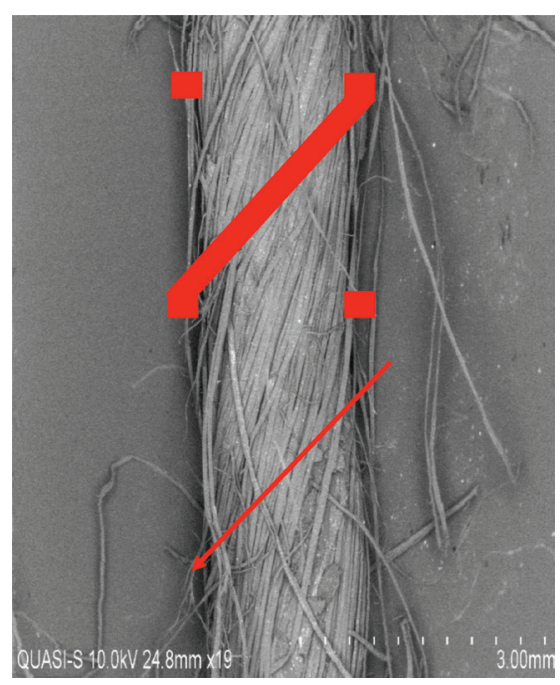

FIGURE 1. Twist direction of kenaf yarn

The principle in the yarn making is by twisting the fibre together during spinning and the yarn twist binds fibres together and give yarn strength, at the same time producing a continuous length of yarn. It is a strong relationship between twist angle and twist number, where the twist angle depends on number of twist for the same yarn size/tex. The twist angle of yarn was found slightly different in all yarns linear density as shown in Table 2. Basically, for a certain length of yarn (in this study 1000 $\mathrm{m})$, the twist angle is governed by the yarn diameter. The greater the diameter of the yarn, the greater the angle of twist. It is observed that higher tex yarn, has a higher twist angle than lower tex yarn, in spite of having a lower twist angle due to the fact that heavier yarn has more fibres and larger yarn diameter. For heavier yarn, more twist is needed for the fibers to become more compact. The range of twist number is between 140 and 152 with the average twist per meter (tpm) is about 146 . The twist number becomes larger as the number of fibres increases. In the case of 500 tex yarn, only 140 tpm twist required during spinning to produce acceptable yarn quality compared to 2000 tex yarn that required $152 \mathrm{tpm}$. The twist number required for the high linear density of yarn is higher than the normal use since more twist required to bind the fibres together. The increment in twist number also affects other important yarn properties such as yarn strength and flexibility.

The SEM images in Figure 2 shows that the whole structure of the kenaf yarns can be described as abundant of individual fibres that are twisted together. In linear density system, the finer the yarn, the lower is the linear density. In this study, tex system is used and this unit is 
TABLE 2. Twist angle and twist number of kenaf yarn for each types

\begin{tabular}{ccc}
\hline $\begin{array}{c}\text { Yarn linear density } \\
(\text { tex })\end{array}$ & $\begin{array}{c}\text { Twist angle } \\
\left({ }^{\circ}\right)\end{array}$ & $\begin{array}{c}\text { Twist number } \\
(\text { tpm })\end{array}$ \\
\hline 500 & 62 & 140 \\
1000 & 64 & 144 \\
1500 & 67 & 147 \\
2000 & 69 & 152 \\
\hline
\end{tabular}
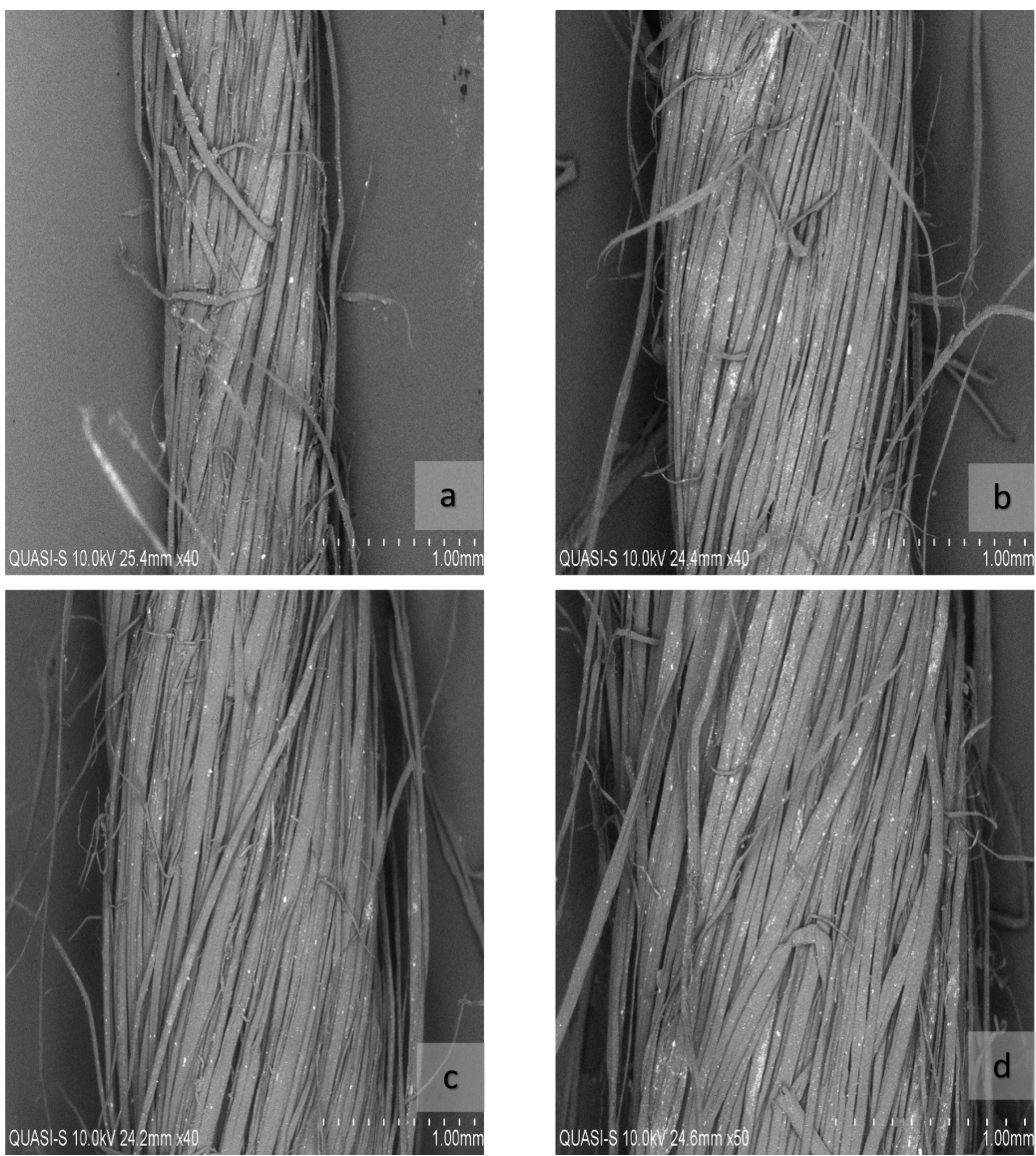

FIGURE 2. Micrograph images of different linear density of kenaf yarn, (a) 500 tex,

(b) 1000 tex, (c) 1500 tex and (d) 2000 tex

referring to the weight of yarn (g) for a length of 1000 $\mathrm{m}$. It is clearly that yarn with higher linear density is wider larger in diameter. It was found that the hairiness of the yarn increases with the increase in linear density due to more number of fibres in the yarn cross-section. This is in consistent with a study conducted by Kadoğlu (2006) who found a direct relationship between yarn linear density and hairiness. They also concluded that yarn linear density is the most important parameter that affects the hairiness. Madsen et al. (2007) mentioned that the higher linear density of yarn means the higher the fibre loading inside the composite which in relation with the mechanical properties of the composite until certain point.
TABLE 3. Yarn diameter of of kenaf yarn for each type

\begin{tabular}{cc}
\hline Yarn linear density (tex) & Yarn diameter $(\mathrm{mm})$ \\
\hline 500 & 1.07 \\
1000 & 1.74 \\
1500 & 1.87 \\
2000 & 1.94 \\
\hline
\end{tabular}

\section{YARN LINEAR DENSITY, FIBRE DENSITY} AND MOISTURE CONTENT

The single factor analysis of variance (ANOVA) on the linear density, fibre density and moisture content of kenaf yarn are shown in Table 4. Significant effects were found on linear density at $p \leq 0.01$, fibre density at $p \leq 0.01$ and 


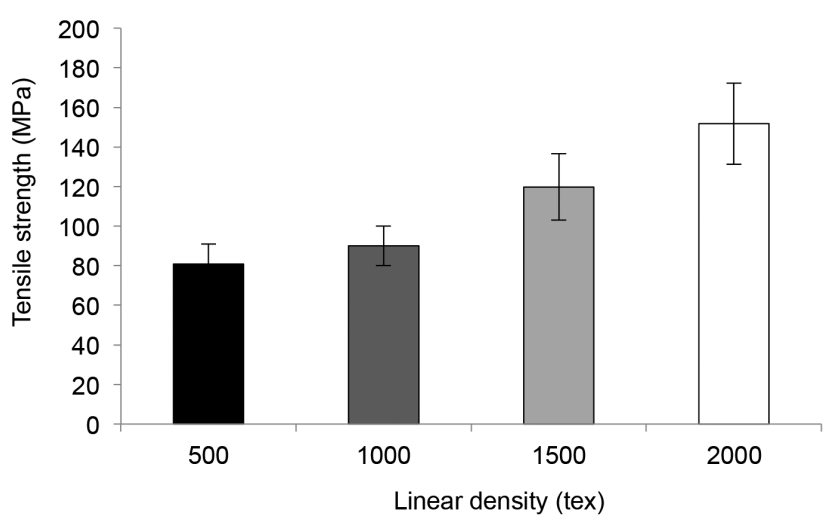

Bar graph indicates the standard deviation of tensile strength for linear density of all yarns. Means followed by the same letters are not significantly different at $p \leq 0.05$

FIGURE 3. Tensile strength of kenaf yarn at different linear densities

TABLE 4. Summary of single factor ANOVA on the linear density, fibre density and moisture content of kenaf yarn

\begin{tabular}{ccccc}
\hline \multirow{2}{*}{ Variables } & d.f & \multicolumn{3}{c}{ Sig. } \\
\cline { 3 - 5 } & & $\begin{array}{c}\text { Linear } \\
\text { density }\end{array}$ & $\begin{array}{c}\text { Fibre } \\
\text { density }\end{array}$ & $\begin{array}{c}\text { Moisture } \\
\text { content }\end{array}$ \\
\hline Tex $(\mathrm{T})$ & 3 & $* * *$ & $* * *$ & $* *$ \\
\hline
\end{tabular}

$* * *$ : Significantly different at $p \leq 0.01, * *$ :Significantly different at $p \leq 0.05$

moisture content at $p \leq 0.5$. The calculated yarn linear density, fibre density and moisture content of kenaf yarns are presented in Table 5 .

In this study, the measurement of yarn linear densities showed that kenaf yarns have slightly different linear density specification provided by the company. The specification given was about 1.2 to $5.0 \%$ lower than the measurement determined.

The fibre densities were well correlated with the yarn linear density values. The results show a consistent trend that for each yarn type, the fibre density is higher as linear density increases. Higher fibre density was found in the 2000 tex yarn that had higher linear density. It is well known that fibre density associated with the types of plant density and kenaf fibre density was reported in the range of 1.0 to $1.5 \mathrm{~g} / \mathrm{cm}^{3}$ (Mossello et al. 2010; Oksman et al. 2003). Thus, yarn with higher linear density, contains more fibres and forms higher yarn density, as well as higher cellulose content (61-65\% of cellulose) (Sulaiman et al. 2015). This is consistent with the study by Madsen et al. (2007), who found that hemp yarn with 47 tex of linear density has fibre density of $1.581 \mathrm{~g} / \mathrm{cm}^{3}$ compared to hemp yarn with 53 tex that has $1.59 \mathrm{~g} / \mathrm{cm}^{2}$.

Table 5 shows that the moisture absorption of kenaf yarns are different with each other, where the moisture content of 2000 and 500 tex are $7.79 \%$ and $5.59 \%$, respectively. The difference in moisture content can be anticipated from the linear density of the yarn types. The linear density of 2000 tex is about $23-25 \%$ higher than
500 tex yarn, thus it contains more number of fibre, in form of single or bundle of fibre. Higher number of fibres corresponds to the larger moisture absorption capacity of 2000 tex yarn compare to other yarns. The result also shows the moisture content of all yarns increase proportional to the increment in linear density.

TABLE 5. Effects of linear density on calculated yarn linear density, fibre density and moisture content of kenaf yarns

\begin{tabular}{cccc}
\hline $\begin{array}{c}\text { Yarn linear } \\
\text { density } \\
(\text { Tex })\end{array}$ & $\begin{array}{c}\text { Calculated } \\
\text { linear density } \\
(\text { Tex })\end{array}$ & $\begin{array}{c}\text { Fibre } \\
\text { density } \\
\left(\mathrm{g} / \mathrm{cm}^{3}\right)\end{array}$ & $\begin{array}{c}\text { Moisture } \\
\text { content } \\
(\%)\end{array}$ \\
\hline 500 & $525^{\mathrm{a}}$ & $0.34^{\mathrm{a}}$ & $5.29^{\mathrm{b}}$ \\
1000 & $1103^{\mathrm{b}}$ & $1.09^{\mathrm{b}}$ & $5.59^{\mathrm{b}}$ \\
1500 & $1519^{\mathrm{c}}$ & $1.21^{\mathrm{c}}$ & $6.84^{\mathrm{a}}$ \\
2000 & $2131^{\mathrm{d}}$ & $1.54^{\mathrm{d}}$ & $7.79^{\mathrm{a}}$ \\
LSD & 165.83 & $0.0904^{3}$ & 1.6888 \\
\hline
\end{tabular}

Means followed by the same letters are not significantly different at $p \leq 0.05$ according to least significant difference (LSD) method

\section{YARN MECHANICAL PROPERTIES}

The single factor analysis of variance (ANOVA) on the breaking load, tensile strength and elongation of yarns are shown in Table 6 . There were found to be significant at $p \leq 0.01$ on all mechanical properties of the yarns.

The tensile strength and Young's Modulus of yarns are illustrated in Figures 3 and 4, respectively. Generally, the

TABLE 6. Summary of single factor ANOVA on the mechanical properties of kenaf yarn

\begin{tabular}{ccccc}
\hline & & \multicolumn{3}{c}{ Sig. } \\
\cline { 3 - 5 } Variables & d.f & $\begin{array}{r}\text { Tensile } \\
\text { strength }\end{array}$ & $\begin{array}{c}\text { Young } \\
\text { modulus }\end{array}$ & Elongation \\
\hline Tex $(\mathrm{T})$ & 3 & $* * *$ & $* * *$ & $* * *$ \\
\hline
\end{tabular}

$* * *$ : Significantly different at $p \leq 0.01$ 


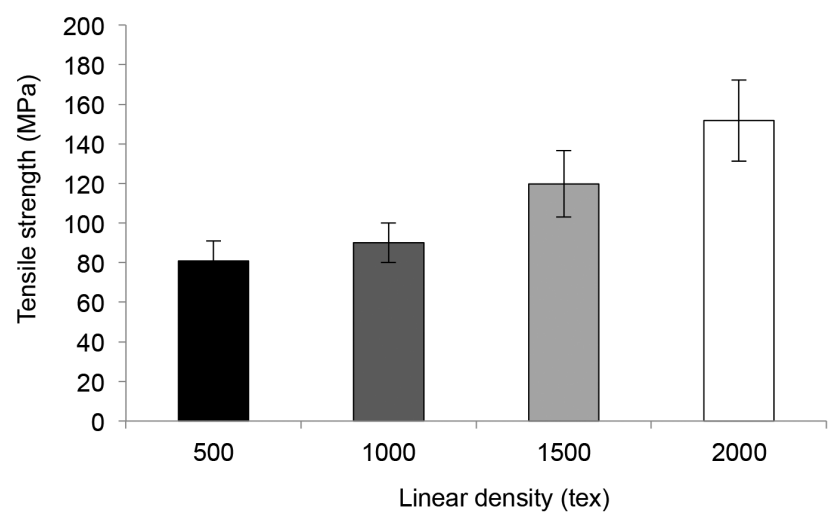

Bar graph indicates the standard deviation of Young Modulus for linear density of all yarns. Means followed by the same letters are not significantly different at $p \leq 0.05$

FIGURE 4. Young's Modulus of kenaf yarn at different linear densities

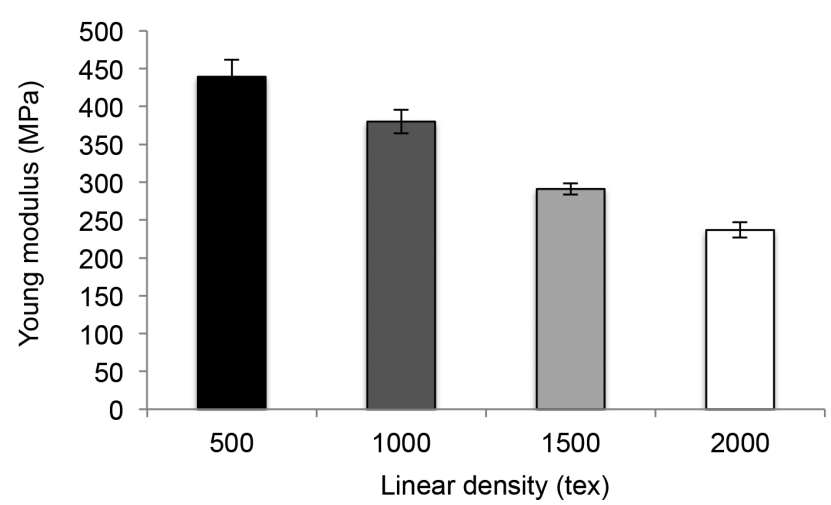

Bar graph indicates the standard deviation of elongation for linear density of all yarns. Means followed by the same letters are not significantly different at $p \leq 0.05$

FIGURE 5. Elongation of kenaf yarn at different linear densities

tensile strength is directly proportional with the yarn linear density. It shows an increasing pattern from $80.8 \mathrm{~N}$ in 500 tex yarn to $83.8 \mathrm{~N}$ in 1000 tex yarn and further increase to $119.7 \mathrm{~N}$ and $151.7 \mathrm{~N}$ in 1500 tex yarn and 2000 tex yarn, respectively. These results correspond with previous study conducted by Shah et al. (2013) on the increment of yarn tensile strength to higher linear density. Tensile strength depends on the yarn density and cross-section area, thus 2000 tex yarn exhibits higher tensile strength because of high fibre density. Furthermore, heavier yarn consists of higher amount of individual fibres, thus require bigger load to break. This can be explained by the loose and twisted fibre structure in the yarn where only minor fibre fraction of yarn are strained, whereas the remaining fibres are free to move inwards before tensile strain is developed. One of the main factors is higher degree of twist that increases the yarn strength. The cohesive force among the fibres developed during twisting in spinning process will result in the higher tensile strength by making the yarn stronger and compact. Low degree of twisting makes the yarn break easily because of fibre slippage.

An opposite observation was seen in Young's Modulus strength of the yarn as can be seen in Figure 4. Significant high stiffness was found in the yarn made from low linear density. Changing the linear density from 1000 to 1500 and 2000 tex reduces the yarn stiffness significantly as indicated by the different letter. The lowest stiffness value of $236 \mathrm{MPa}$ was found for yarn with 2000 tex. It seems that moisture content (Table 3) is the dominant factor affecting the Young's Modulus values of the yarn. This is also supported by a study from Madsen et al. (2007) who found that the moisture content and humidity are inversely proportional with the yarn stiffness. This is because the moisture in the fibres interrupts the intermolecular hydrogen bonds in the cell wall, causing the mobility of polymer chain to increase. The higher moisture also has broken the bond between fibres in the outer layer of the cell wall. Other explanation might be due to the high twist number and angle, where the fibres angle becomes more oblique.

As displayed in Figure 5, elongation of the yarn increases significantly with the increasing linear density. The measured elongation at break decreases as the yarn becomes thinner. These findings show that, high amount of fibres in the thicker yarn enhances fibre to fibre friction, thus reducing the fibre sliding. In addition, it can be noted 
that yarn irregularity deteriorates to a larger extent in the thinner yarn.

\section{CONCLUSION}

There are many other variables which influence the strength property of yarn. Yarn at different linear density exhibits different behaviour of yarn properties. Higher linear density yarn produces wider yarn diameter compared to the lower linear density one, thus having yarn with more amount of fibres and higher moisture content. The changes in yarn linear density are clear in yarn tensile strength when yarn linear density is 1000 tex and above. However, in term of Young's Modulus, the values reduce as the yarn linear density increases.

\section{CONTRIBUTION TO THE KNOWLEDGE}

The study provides a fundamental knowledge and understanding on the yarn properties for woven laminated composite fabrication. It provides a useful basis for the selection of yarn with different linear densities in the production of fabric designates for various different applications. Yarn linear density and strength play an important role on the performance of woven fabric and its resultant laminated composite. The findings from this study revealed that, with proper selection of yarn linear density,kenaf yarn is suitable for woven structural composite production.

\section{REFERENCES}

Abdellaoui, H., Bensalah, H., Echaabi, J., Bouhfid, R. \& Qaiss, A. 2015. Fabrication, characterization and modelling of laminated composites based on woven jute fibres reinforced epoxy resin. Materials and Design 68: 104-113.

Alavudeen, A., Rajini, N., Karthikeyan, S., Thiruchitrambalam, M. \& Venkateshwaren, N. 2015. Mechanical properties of banana/kenaf fiber-reinforced hybrid polyester composites: Effect of woven fabric and random orientation. Materials and Design 66: 246-257.

Azrin Hani Abdul, R., Roslan, A., Jaafar, M., Roslan, M.N. \& Ariffin, S. 2011. Mechanical properties evaluation of woven coir and kevlar reinforced epoxy composites. Advanced Materials Research 277: 36-42.

Baghaei, B., Skrifvars, M. \& Berglin, L. 2015. Characterization of thermoplastic natural fibre composites made from woven hybrid yarn prepregs with different weave pattern. Applied Science and Manufacturing 76: 154-161.

Bodros, E. \& Baley, C. 2008. Study of the tensile properties of stinging nettle fibres (Urtica dioica). Materials Letters 62(14): 2143-2145.

Chattopadhyay, R. 2008. Design of apparel fabrics: Role of fibre, yarn and fabric parameters on its functional attributes. Journal of Textile Engineering 54(6): 179-190.

Dalbehera, S. \& Acharya, S.K. 2015. Effect of cenosphere addition on erosive wear behaviour of jute-glass reinforced composite using taguchi experimental design. Materials Today: Proceedings 2(4-5): 2389-2398.

Duval, A., Bourmaud, A., Augier, L. \& Baley, C. 2011. Influence of the sampling area of the stem on the mechanical properties of hemp fibers. Materials Letters 65(4): 797-800.
Faruk, O., Bledzki, A.K., Fink, H.P. \& Sain, M. 2012. Biocomposites reinforced with natural fibers: 2000 2010. Progress in Polymer Science 37(11): 1552-1596.

Gabrijelcic, H., Cernosa, E. \& Dimitrovski, K. 2008. Influence of weave and weft characteristics on tensile properties of fabrics. Fibres and Textiles in Eastern Europe 2(67): 45-51.

Goutianos, S., Peijs, T., Nystrom, B. \& Skrifvars, M. 2006. Development of flax fibre based textile reinforcements for composite applications. Applied Composite Materials 13(4): 199-215.

Hani, A., Rashid, A., Seang, C.T., Ahmad, R. \& Mariatti, J.M. 2013. Impact and flexural properties of imbalance plain woven coir and kenaf composite. Applied Mechanics and Materials 271: 81-85.

Jawaid, M., Khalil, H.A. \& Bakar, A.A. 2011. Woven hybrid composites: Tensile and flexural properties of oil palm-woven jute fibres based epoxy composites. Materials Science and Engineering 528(15): 5190-5195.

Júnior, C.P., De Carvalho, L.H., Fonseca, V.M., Monteiro, S.N. \& d'Almeida, J.R.M. 2004. Analysis of the tensile strength of polyester/hybrid ramie-cotton fabric composites. Polymer Testing 23(2): 131-135.

Kadoğlu, H. 2006. Determining fibre properties and linear density effect on cotton yarn hairiness in ring spinning. Fibres and Textiles in Eastern Europe 3(57): 48-51.

Khan, G.A., Terano, M., Gafur, M.A. \& Alam, M.S. 2016. Studies on the mechanical properties of woven jute fabric reinforced poly (1-lactic acid) composites. Journal of King Saud University-Engineering Sciences 28(1): 69-74.

Le Duigou, A., Deux, J.M., Davies, P. \& Baley, C. 2011. PLLA/ flax mat/balsa bio-sandwich manufacture and mechanical properties. Applied Composite Materials 18(5): 421-438.

Liu, Q. \& Hughes, M. 2008. The fracture behaviour and toughness of woven flax fibre reinforced epoxy composites. Applied Science and Manufacturing 39(10): 1644-1652.

Madsen, B., Hoffmeyer, P., Thomsen, A.B. \& Lilholt, H. 2007. Hemp yarn reinforced composites-I. Yarn characteristics. Applied Science and Manufacturing 38(10): 2194-2203.

Me, R.C., Ibrahim, R. \& Tahir, P.M. 2012. Natural based biocomposite material for prosthetic socket fabrication. ALAM CIPTA, International Journal of Sustainable Tropical Design Research and Practice 5(1): 27-34.

Mollanoori, M. \& Alamdar-Yazdi, A. 2012. Twist direction effect on the mechanical properties of woven fabric. Fibres \& Textiles in Eastern Europe 5(94): 48-55.

Mossello, A.A., Harun, J., Shamsi, S.R.F., Resalati, H., Tahir,P.M., Ibrahim, R.\& Mohmamed, A.Z. 2010. A review of literatures related to kenaf as a alternative for pulpwoods. Agricultural Journal 5(3): 131-138.

Ochi, S. 2008. Mechanical properties of kenaf fibers and kenaf/ PLA composites. Mechanics of Materials 40(4-5): 446-452.

Oksman, K., Skrifvars, M. \& Selin, J.F. 2003. Natural fibres as reinforcement in polylactic acid (PLA) composites. Composites Science and Technology 63(9): 1317-1324.

Pothan, L.A., Oommen, Z. \& Thomas, S. 2003. Dynamic mechanical analysis of banana fiber reinforced polyester composites. Composites Science and Technology 63(2): 283-293.

Saiman, M.P., Wahab, B., Saidin, M. \& Wahit, M.U. 2014. The effect of yarn linear density on mechanical properties of plain woven kenaf reinforced unsaturated polyester composite. Applied Mechanics and Materials 465: 962-966. 
Sapuan, S.M., Leenie, A., Harimi, M. \& Beng, Y.K. 2006. Mechanical properties of woven banana fibre reinforced epoxy composites. Materials and Design 27(8): 689-693.

Sapuan, S.M. \& Maleque, M.A. 2005. Design and fabrication of natural woven fabric reinforced epoxy composite for household telephone stand. Materials and Design 26(1): 65-71.

Satyanarayana, K.G., Arizaga, G.G. \& Wypych, F. 2009. Biodegradable composites based on lignocellulosic fibersAn overview. Progress in Polymer Science 34(9): 982-1021.

Shah, D.U., Schubel, P.J. \& Clifford, M.J. 2013. Modelling the effect of yarn twist on the tensile strength of unidirectional plant fibre yarn composites. Journal of Composite Materials 47(4): 425-436.

Song, Y.S., Lee, J.T., Ji, D.S., Kim, M.W., Lee, S.H. \& Youn, J.R. 2012. Viscoelastic and thermal behavior of woven hemp fiber reinforced poly (lactic acid) composites. Engineering 43(3): 856-860.

Sulaiman, S., Mokhtar, M.N., Naim, M.N., Baharuddin, A.S., Salleh, M.A.M. \& Sulaiman, A. 2015. Study on the preparation of cellulose nanofibre $(\mathrm{CNF})$ from kenaf bast fibre for enzyme immobilization application. Sains Malaysiana 44(11): 1541-1550.

Summerscales, J., Dissanayake, N., Virk, A. \& Hall, W. 2010. A review of bast fibres and their composites. Applied Science and Manufacturing 41(10): 1336-1344.

Yahaya, R., Sapuan, S.M., Jawaid, M., Leman, Z. \& Zainudin, E.S. 2015. Effect of layering sequence and chemical treatment on the mechanical properties of woven kenaf-aramid hybrid laminated composites. Materials and Design 67: 173-179.
Khalina Abdan

Department of Biocomposite Technology

Faculty of Engineering

Universiti Putra Malaysia

43400 UPM Serdang, Selangor Darul Ehsan

Malaysia

Mohd Sapuan Salit

Faculty of Engineering

Universiti Putra Malaysia

43400 UPM Serdang, Selangor Darul Ehsan

Malaysia

Md. Saidin Wahab

Faculty of Mechanical Engineering

Universiti Tun Hussien Onn Malaysia (UTHM)

86400 Batu Pahat, Johor Darul Takzim

Malaysia

Mohd Pahmi Saiman

Politeknik Seberang Perai (PSP)

Jalan Permatang Pauh

13500, Permatang Pauh, Pulau Pinang

Malaysia

*Corresponding author; email: a.humaira.aisyah@gmail.com

Received: 29 May 2017

Accepted: 14 April 2018
Aisyah Humaira Alias* \& Paridah Md. Tahir

Institute of Tropical Forestry and Forest Product (INTROP)

Universiti Putra Malaysia

43400 UPM Serdang, Selangor Darul Ehsan

Malaysia 